\title{
PENGARUH PELATIHAN DAN PROMOSI TERHADAP MOTIVASI DAN KINERJA KARYAWAN (Studi pada Karyawan PT.PLN (Persero) Area Kendari)
}

\author{
Citra Ayu Ningsi, Taher Alhabsji, Hamidah Nayati Utami \\ Universitas Brawijaya \\ Email: Fortune.citra@gmail.com
}

\begin{abstract}
ABSTRAK
Tujuan penelitian ini adalah untuk mengetahui dan menjelaskan pengaruh pelatihan terhadap motivasi, pengaruh pelatihan terhadap kinerja karyawan, pengaruh promosi terhadap motivasi, pengaruh promosi terhadap kinerja karyawan dan pengaruh motivasi terhadap kinerja karyawan. Penelitian ini menggunakan pendekatan kuantitatif dengan menggunakan metode survei (explanatory research) dan menggunakan analisis path. Hasil penelitian ini menyatakan pelatihan berpengaruh signifikan dan positif terhadap motivasi, promosi berpengaruh signifikan dan positif terhadap motivasi, promosi berpengaruh signifikan dan positif terhadap kinerja karyawan, motivasi berpengaruh signifikan dan positif terhadap kinerja karyawan. Namun, pelatihan berpengaruh tidak signifikan dan positif terhadap kinerja karyawan.
\end{abstract}

Kata Kunci : Pelatihan, Promosi, Motivasi dan Kinerja Karyawan

\section{PENDAHULUAN}

Perusahaan listrik Negara (PLN) adalah badan usaha milik Negara (BUMN) yang diberikan kewenangan oleh pemerintah dan diserahi tugas semata-mata untuk melaksanakan usaha penyediaan tenaga listrik untuk kepentingan umum, serta diberikan tugas untuk melaksanakan pekerjaan usaha penunjang tenaga listrik Begitu pula, PT. PLN (Persero) Area Kendari juga merupakan Badan Usaha Milik Negara (BUMN) atau instansi pemerintah yang bergerak dalam industri tenaga listrik dan memberi jasa ketenagalistrikan pada masyarakat khususnya sekitar wilayah kota Kendari.

Pelatihan lebih terorientasi pada peningkatan motivasi dalam meningkatakan semangat kerja karyawan dan kemampuan untuk melakukan pekerjaan yang spesifik dan pengembangan lebih ditekankan untuk melakukan pekerjaan pada masa yang akan datang. Adapun pelatihan di PT. PLN dilakukan dengan metode latihan (training) dan pendidikan (education), selain itu perusahaan juga melakukan program pelatihan dan pengembangan lainnya, yaitu : metode on the job training yang meliputi pembekalan (coaching), rotasi jabatan (job rotation), penugasan sementara (job instruction training), magang (apprenticeship training) dan off the job training yang meliputi diklat teknisi.

Menurut penelitian yang dilakukan Aryani et al (2010) terdapat pengaruh antara promosi jabatan dengan kinerja karyawan. Hal ini menunjukkan setiap kenaikan sistem promosi akan meningkat besarnya pengaruh sistem promosi jabatan terhadap kinerja karyawan ini dikarenakan 
karyawan menilai bahwa promosi jabatan merupakan salah satu bentuk kepercayaan dan penghargaan perusahaan terhadap kinerja karyawan. Tapi masalah yang terjadi pada PT. PLN (Persero) area Kendari meskipun sering mengalami promosi jabatan tapi masih ada karyawan yang belum mengerti mengenai tugas dan tanggung jawabnya sehingga kinerjanya tidak mengalami peningkatan malah terjadi penurunan.

Menurut Mathis dan Jackson (2001:114) menyatakan bahwa motivasi merupakan suatu keinginan dalam diri seseorang yang menyebabkan orang tersebut melakukan tindakkan. Dalam hal ini, sesuai pendapat Standford dalam Mangkunegara (2009:93) yang menyatakan bahwa motivasi sebagai suatu kondisi yang menggerakkan manusia kearah suatu tujuan tertentu.

Menurut Mangkunegara (2002:63) mengatakan bahwa kinerja merupakan suatu hasil yang dicapai seseorang dalam melakukan tugas, baik secara kualitas dan kuantitas sesuai tanggung jawab yang diberikan kepadanya yang didasarkan atas kecakapan, pengalaman, kesungguhan serta waktu. Dalam kata lain, bahwa kinerja adalah gabungan dari tiga faktor penting yaitu kemampuan dan minat seorang pekerja, kemampuan dan penerima atas penjelasan delegasi tugas dan peran serta tingkat karyawan yang bersangkutan

Tujuan penelitian ini (1) Untuk mengetahui dan menjelaskan pengaruh pelatihan terhadap motivasi. (2) Untuk mengetahui dan menjelaskan pengaruh pelatihan terhadap kinerja karyawan. (3) Untuk mengetahui dan menjelaskan pengaruh promosi terhadap motivasi. (4) Untuk mengetahui dan menjelaskan pengaruh promosi terhadap kinerja karyawan. (5) Untuk mengetahui dan menjelaskan pengaruh motivasi terhadap kinerja karyawan.

\section{KAJIAN TEORI}

\section{Pelatihan}

Menurut Mangkuprawira (2002:122) merupakan sebuah proses mengajarkan Pengetahuan dan keahlian tertentu serta sikap agar karyawan semakin terampil dan mampu melaksanakan tanggung jawabnya dengan semakin baik, sesuai dengan standar. Pelatihan adalah suatu proses pendidikan jangka pendek yang mempergunakan prosedur sistematis dan terorganisasi, pegawai non manajerial mempelajari pengetahuan dan keterbatasan teknis dalam tujuan yang terbatas.

\section{Promosi}

Adapun penetapan Kriteria untuk promosi Menurut Ardana I Komang et al (2012:107) mengemukakan ada beberapa kriteria umum yang perlu dipertimbangkan dalam rangka, promosikan tenaga kerja. Kriteria yang dimaksud antara lain sebagai berikut:

1. Senioritas

Tingkat senioitas tenaga kerja dalam banyak hal serikali digunakan sebagai salah satu standar untuk kegiatan promosi. Dengan alasan bahwa dengan tingkat senioritas yang tinggi pengalaman yang dimiliki dianggap lebih banyak ketimbang angkatan muda. Sehingga diharapkan tenaga kerja yang bersangkutan mempunyai kemampuan yang lebih tinggi, gagasan yang lebih banyak, pada manajerial yang rasional dan sebagainya.

2. Kualitas pendidikan

Walaupun amat langka, tetapi terdapat pila perusahaan yang menjadi kriteria minimal tingkat pendidikan tenaga kerja yang bersangkutan untuk dapat dipromosikan pada jabatan tertentu. Alasan yang melatar belakangi adalah bahwa dengan adanya latar belakang pendidikan yang lebih 
tinggi diharapkan mempunyai daya nalar yang tinggipula terhadap prospek perkembangan perusahaan diwaktu mendatang.

3. Prestasi Kerja

Hampir semua perusahan menjadikan prestasi kerja yang dicapai oleh tenaga kerja yang bersangkutan dijadikan salah satu kriteria untuk kegiatan promosi. Prestasi kerja yang tinggi mempunyai kecenderungan untuk memperlancarkan kegiatan promosi bagi tenaga kerja yang bersangkutan, demikian pula kecenderungan sebaliknya.

4. Karsa dan daya cipta

Untuk kegiatan promosi pada jenis pekerjaan tertentu barangkali karsa dan daya cipta merupakan salah satu syarat yang tidak perlukan ditawar lagi. Hal ini disebabkan karena untuk jenis pekerjaan tertentu sangat diperlukan karsa dan daya cipta demi kontinuitas perusahaan, sehingga pelaksanaan promosi bagi tebaga kerja mempunyai dampak meningkatnya tingakat profitable yang tinggi ketimbang waktu sebelumnya.

5. Tingkat loyalitas

Tingkat loyalitas tenaga kerja terhadap perusahaan seringkali merupakan salah satu kriteria untuk kegiatan promosi. Hal ini dimaksudkan dengan tingkat loyalitas yang tinggi dapat diperoleh dampak tanggung jawab yang lebih besar.

6. Kejujuran

Khusus pada jabatan-jabatan tertentu yang berhubungan dengan Finansial, Produksi, Marketing, dan sejenisnya memerlukan kriteria kejujuran yang dipandang amat penting. Hal ini dimaksudkan untuk menjaga jangan sampai dengan kegiatan promosi malahan bakal merugikan perusahaan, karena tindakan ketidak

\begin{abstract}
jujuran tenaga kerja yang dipromosikan.

7. Supelitas

Pada jenis pekerjaan/ jabatan tertentu barangkali diperlukan kepandaian bergaul, sehingga kriteria kemampuan bergaul dengan orang lain perlu dijadikan salah satu standar untuk promosi pada pekerjaan/ jabatan tersebut.
\end{abstract}

\section{Motivasi}

Dalam teori ini dikemukakan oleh Alderfer dalam (Hariandja,2002:332) yang mengatakan bahwa terdapat tiga kelompok kebutuhan manusia, yaitu:

1. Kebutuhan keberadaan (existence needs)

Kebutuhan ini berkaitan dengan kebutuhan untuk mempertahankan keberadaan seseorang dalam hidupnya. Dihubungan dengan Maslow ini berkaitan dengan kebutuhan fisik dan keamanan.

2. Kebutuhan keterkaitan (relatedness needs)

Kebutuhan ini berkaitan dengan kebutuhan untuk berinteraksi dengan orang lain. Berhubungan dengan penggolongan kebutuhan dari Maslow, ini terdiri dari kebutuhan sosial dan pengakuan.

3. Kebutuhan pertumbuhan (growth needs)

Kebutuhan ini berhubungan dengan kebutuhan pengembangan diri, yang identik dengan kebutuhan self actualization yang dikemukakan Maslow.

\section{Kinerja Karyawan}

Menurut Mangkunegara (2005 : 67) Hal-hal yang menjadi pertimbangkan dalam pengukur kinerja merupakan antara lain:

a. Ketepatan waktu, adalah hasil kerja pegawai /karyawan dalam melaksanakan tugas-tugas yang 
dikerjakan tepat sesuai waktu yang efisien.

b. Kuantitas kerja adalah hasil kerja pegawai/karyawan yang didasarkan pada pencapaian target yang sudah distandarkan jumlah waktunya dalam waktu tertentu oleh atasan atau organisasi

c. Kualitas kerja adalah hasil kerja pegawai/ karyawan didasarkan pada mutu pekerjaan yang dilakukan oleh pegawai, apakah hasil pekerjaannya memenuhi mutu hasil pekerjaan seperti yang ditetapkan dalam standar mutu.

Menurut Mathis dan Jackson (2000:381) “employee's performance can be measured by the quantity of output, quality of output, timeliness of output, presence at work and cooperativeness", artinya kinerja karyawan dapat diukur melalui kuantitas output, kualitas output, jangka waktu output, kehadiran ditempat kerja dan sikap komperatif.

\section{METODE PENELITIAN}

Metode yang digunakan dalam penelitian ini adalah penelitian explanatory, serta menggunakan jenis pendekatan kualitatif dengan menggunakan alat analisis path dan uji validitas dan uji reliabilitas. Data yang digunakan data primer adalah data yang diperoleh langsung dari responden yaitu melalui penyebaran kuesioner, dan data sekunder yang diperoleh dari dokumen berupa identitas karyawan, struktur organisasi dan uraiannya, sejarah perusahaan, visi dan misi, dan produk PT. PLN. Dan skala likert digunakan untuk memberikan bobot nilai dalam kuesioner.

Dalam penelitian ini menjelaskan pengaruh antara variabel-variabel penelitian dan menguji hipotesis yang telah dirumuskan. Pengaruh antara variabel yang diteliti yakni mengenai pengaruh pelatihan dan promosi terhadap motivasi dan kinerja karyawan. adapun populasi dalam penelitian ini adalah seluruh karyawan pada PT. PLN (Persero) Area Kendari dengan menggunakan sampel jenuh adalah sensus, dimana seluru anggota populasi dijadikan sampel" (2008:82). Pada penelitian ini pengumpulan data dilakukan dengan teknik penyebaran kuesioner kepada responden, lalu kuesioner ditabulasikan kepada respoonden, diolah menggunakan statistik SPSS, setelah itu hasil output SPSS dianalisis. Penelitian ini dilakukan pada karyawan PT. PLN (Persero) Area Kendari, Jalan A. Yani Wua-Wua, Kendari, Sulawesi Tenggara.. Dalam penelitian ini menggunakan rumus analisis path yaitu untuk mengukur seberapa jauh pengaruh pelatihan dan promosi terhadap motivasi dan kinerja karyawan, dengan analisa yang digunakan analisis path. Maka dapat dirumuskan sebagai berikut :

$\mathrm{Y}_{1}=\mathrm{p} \mathrm{y}_{1} \mathrm{x}_{1} \mathrm{X}_{1}+\mathrm{py}_{1} \mathrm{x}_{2} \mathrm{X}_{2} \cdot \varepsilon_{1}$

$\mathrm{Y}_{2}=\mathrm{py}_{2} \mathrm{x}_{1} \mathrm{X}_{1}+\mathrm{py}_{2} \mathrm{x}_{2} \mathrm{X}_{2}+\mathrm{py}_{2} \mathrm{y}_{1} \mathrm{Y}_{1} \cdot \varepsilon_{2}$

Dimana:

$\mathrm{X}_{1}=$ Pelatihan

$\mathrm{X}_{2}=$ Promosi

$\mathrm{Y}_{1}=$ Motivasi

$\mathrm{Y}_{2}=$ Kinerja Karyawan

\section{HASIL DAN PEMBAHASAN}

\section{Hasil Penelitian}

Menurut Sugiyono (2008:137) mengatakan bahwa instrument pengumpulan data dikatakan valid apabila mampu dan dapat mengungkapkan data dan informasi dari variabel yang diteliti secara tepat dan mampu diukur apa yang diinginkan atas penelitian tersebut. Dalam hal ini uji validitas dimaksudkan untuk melihat konsistensi variabel bebas dengan apa yang akan diukur. Uji reliabel bermaksud untuk mengetahui adanya konsistensi alat ukur dalam penggunaanya, atau dengan kata lain alat ukur tersebut mempunyai konsistensi apabila digunakan berulang-ulang pada waktu yang berbedabeda di dalam mengukur gelaja yang sama, hasilnya akan sama (Sugiono,2008:141). 


\section{Pelatihan $\left(\mathbf{X}_{1}\right)$}

Hasil koefisien korelasi dan Cronbach Alpha untuk menguji validitas dan reliabilitas penggunaan item pernyataan dari indikator-indikator variabel pelatihan pada tabel 1

Tabel 1

Hasil Uji Reliabilitas dan Validitas Variabel Pelatihan $\left(\mathbf{X}_{1}\right)$

\begin{tabular}{|c|c|c|c|c|c|c|}
\hline $\begin{array}{c}\text { Indikator } \\
\text { Variabel }\end{array}$ & $\begin{array}{c}\text { Item } \\
\text { Pernyataan }\end{array}$ & $\begin{array}{c}\text { Koofisien } \\
\text { Kolerasi }\end{array}$ & Sig & Ket & $\begin{array}{c}\text { Cronbach } \\
\text { Alpha }\end{array}$ & Ket \\
\hline $\begin{array}{c}\text { Instruktur } \\
\left(\mathrm{X}_{1.1}\right)\end{array}$ & $\mathrm{X}_{1.1 .1}$ & 0,742 & 0,00 & Valid & 0,742 & Reliabel \\
& $\mathrm{X}_{1.1 .2}$ & 0,603 & 0,00 & Valid & & \\
\hline Metode & $\mathrm{X}_{1.1 .3}$ & 0,753 & 0,00 & Valid & & \\
pelatihan & $\mathrm{X}_{1.2 .1}$ & 0,903 & 0,00 & Valid & 0,939 & Reliabel \\
$\left(\mathrm{X}_{1.2}\right)$ & $\mathrm{X}_{1.2 .2}$ & 0,924 & 0,00 & Valid & & \\
\hline Waktu & $\mathrm{X}_{1.3 .1}$ & 0,862 & 0,00 & Valid & & \\
Pelatihan & $\mathrm{X}_{1.3 .2}$ & 0,913 & 0,00 & Valid & 0,911 & Reliabel \\
$\left(\mathrm{X}_{1.3}\right)$ & $\mathrm{X}_{1.3 .3}$ & 0,853 & 0,00 & Valid & & \\
\hline Manfaat & $\mathrm{X}_{1.4 .1}$ & 0,828 & 0,00 & Valid & & \\
pelatihan & $\mathrm{X}_{1.4 .2}$ & 0,569 & 0,00 & Valid & 0,846 & Reliabel \\
$\left(\mathrm{X}_{1.4}\right)$ & $\mathrm{X}_{1.4 .3}$ & 0,773 & 0,00 & Valid & & \\
& $\mathrm{X}_{1.4 .4}$ & 0,590 & 0,00 & Valid & & \\
& $\mathrm{X}_{1.4 .5}$ & 0,814 & 0,00 & Valid & & \\
\hline
\end{tabular}

Sumber : Hasil Pengolahan data primer,2015

Semua indikator pada variabel pelatihan menunjukkan hasil yang valid dan reliabel. Keputusan ini diambil karena nilai koefisien korelasi dan cronbach alpha di atas 0,30 atau 0,60 , dengan tingkat sangat signifikan $(0,000)$. Indikator yang sangat kuat mencerminkan pelatihan secara berurutan adalah metode pelatihan $\left(\mathrm{X}_{1.2}\right)$ dengan nilai cronbach alpha adalah 0,939, Waktu pelatihan $\left(\mathrm{X}_{1.3}\right)$ dengan nilai cronbach alpha adalah 0,911, manfaat pelatihan 0,846 dan instruktur $\left(\mathrm{X}_{1.1}\right)$ dengan nilai cronbach alpha adalah 0,742 .

\section{Promosi $\left(\mathrm{X}_{2}\right)$}

Hasil koefisien korelasi dan cronbach alpha untuk menguji validitas dan reliabilitas penggunaan item pernyataan dari indikator-indikator variabel promosi adalah sebagai berikut:

Tabel 2

Hasil Uji Validitas dan Reliabilitas Variabel Promosi $\left(\mathrm{X}_{2}\right)$

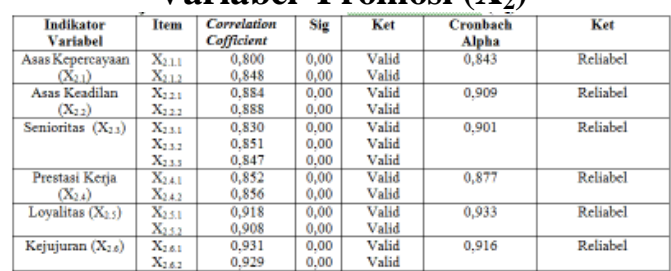

Sumber : Hasil pengolahan data primer 2015
Semua indikator pada variabel promosi pangkat menunjukkan hasil yang valid dan reliabel. Keputusan ini diambil karena nilai koefisien korelasi dan cronbach alpha di atas 0,30 atau 0,60, dengan tingkat sangat signifikan $(0,000)$. Indikator yang sangat kuat mencerminkan promosi pangkat secara berurutan adalah loyalitas $\left(\mathrm{X}_{2.5}\right)$ dengan nilai cronbach alpha adalah 0,933, kejujuran $\left(\mathrm{X}_{2.6}\right)$ dengan nilai cronbach alpha adalah 0,916 , asas keadilan $\left(\mathrm{X}_{2.2}\right) 0,909$, senioritas $\left(\mathrm{X}_{2.3}\right)$ dengan nilai cronbach alpha adalah 0,901 prestasi kerja $\left(\mathrm{X}_{2.4}\right)$ dengan nilai cronbach alpha adalah 0,877 dan Asas kepercayaan $\left(\mathrm{X}_{2.1}\right)$ dengan nilai cronbach alpha adalah 0,843 .

\section{Motivasi $\left(\mathbf{Y}_{1}\right)$}

Hasil koefisien korelasi dan cronbach alpha untuk menguji validitas dan reliabilitas penggunaan item pernyataan dari indikator-indikator variabel motivasi pada tabel 3 .

Tabel 3

Hasil Uji Validitas Dan Reliabilitas Variabel Motivasi $\left(\mathbf{Y}_{1}\right)$

\begin{tabular}{|c|c|c|c|c|c|c|}
\hline $\begin{array}{c}\text { Indikator } \\
\text { Variabel }\end{array}$ & Item & $\begin{array}{c}\text { Correlation } \\
\text { Cofficient }\end{array}$ & Sig & Ket & $\begin{array}{c}\text { Cronbach' } \\
\text { Alpha }\end{array}$ & Ket \\
\hline Kebutuhan & $\mathrm{Y}_{1.1 .1}$ & 0,812 & 0,00 & Valid & 0,916 & Reliabel \\
Eksistensi & $\mathrm{Y}_{1.1 .2}$ & 0,532 & 0,00 & Valid & & \\
(Y.1.1) & $\mathrm{Y}_{1.1 .3}$ & 0,761 & 0,00 & Valid & & \\
& $\mathrm{Y}_{1.1 .4}$ & 0,601 & 0,00 & Valid & & \\
& $\mathrm{Y}_{1.1 .5}$ & 0,885 & 0,00 & Valid & & \\
& $\mathrm{Y}_{1.1 .6}$ & 0,823 & 0,00 & Valid & & \\
& $\mathrm{Y}_{1.1 .7}$ & 0,696 & 0,00 & Valid & & \\
& $\mathrm{Y}_{1.1 .8}$ & 0,902 & 0,00 & Valid & & \\
\hline Kebutuhan & $\mathrm{Y}_{1.2 .1}$ & 0,657 & 0,00 & Valid & 0,899 & Reliabel \\
Relasi $\left(\mathrm{Y}_{1.2 .2}\right)$ & $\mathrm{Y}_{1.2 .2}$ & 0,609 & 0,00 & Valid & & \\
& $\mathrm{Y}_{1.2 .3}$ & 0,675 & 0,00 & Valid & & \\
& $\mathrm{Y}_{1.2 .4}$ & 0,798 & 0,00 & Valid & & \\
& $\mathrm{Y}_{1.2 .5}$ & 0,874 & 0,00 & Valid & & \\
& $\mathrm{Y}_{1.2 .6}$ & 0,750 & 0,00 & Valid & & \\
& $\mathrm{Y}_{1.27}$ & 0,843 & 0,00 & Valid & & \\
\hline Kebutuhan & $\mathrm{Y}_{1.3 .1}$ & 0,865 & 0,00 & Valid & 0,940 & Reliabel \\
Pertumbunan & $\mathrm{Y}_{1.3 .2}$ & 0,829 & 0,00 & Valid & & \\
(Y.1.3) & $\mathrm{Y}_{1.3 .3}$ & 0,845 & 0,00 & Valid & & \\
& $\mathrm{Y}_{1.3 .4}$ & 0,618 & 0,00 & Valid & & \\
& $\mathrm{Y}_{1.3 .5}$ & 0,867 & 0,00 & Valid & & \\
& $\mathrm{Y}_{1.3 .6}$ & 0,824 & 0,00 & Valid & & \\
& $\mathrm{Y}_{1.3 .7}$ & 0,887 & 0,00 & Valid & & \\
\hline
\end{tabular}

Sumber : Hasil Pengolahan Data Primer , 2015

Semua indikator pada variabel motivasi menunjukkan hasil yang valid dan reliabel. Keputusan ini diambil karena nilai koefisien korelasi dan cronbach alpha di atas 0,30 atau 0,60, dengan tingkat sangat signifikan $(0,000)$. Indikator yang sangat kuat mencerminkan motivasi secara berurutan kebutuhan pertumbuhan $\left(\mathrm{Y}_{1.3}\right)$ 
dengan nilai cronbach alpha adalah 0,940, kebutuhan relasi $\left(\mathrm{Y}_{1.1}\right)$ dengan nilai cronbach alpha adalah 0,916 , dan asas keadilan $\left(\mathrm{Y}_{1.2}\right) 0,899$.

\section{Kinerja Karyawan $\left(\mathbf{Y}_{2}\right)$}

Hasil koefisien korelasi dan cronbach alpha untuk menguji validitas dan reliabilitas penggunaan item pernyataan dari indikator-indikator variabel kinerja karyawan adalah sebagai berikut:

\section{Tabel 4}

Hasil Uji Validitas dan Reliabilitas Kinerja Karyawan $\left(\mathbf{Y}_{2}\right)$

\begin{tabular}{|c|c|c|c|c|c|c|}
\hline $\begin{array}{l}\text { Indikator } \\
\text { Variabel }\end{array}$ & $\begin{array}{c}\text { Item } \\
\text { Pernyataan }\end{array}$ & $\begin{array}{l}\text { Koefisisen } \\
\text { Kolerasi }\end{array}$ & Sig & Ket & \begin{tabular}{|c}
$\begin{array}{c}\text { Cronbach' } \\
\text { Alpha }\end{array}$ \\
\end{tabular} & Ket \\
\hline $\begin{array}{c}\text { Kuantitas } \\
\left(\mathrm{Y}_{2.1}\right)\end{array}$ & $\begin{array}{l}\mathrm{Y}_{21.1} \\
\mathrm{Y}_{21.2} \\
\mathrm{Y}_{2.1 .3} \\
\mathrm{Y}_{21.4} \\
\mathrm{Y}_{121}\end{array}$ & $\begin{array}{l}0,812 \\
0,719 \\
0,803 \\
0,686 \\
0,858\end{array}$ & $\begin{array}{l}0,00 \\
0,00 \\
0,00 \\
0,00 \\
0,00\end{array}$ & $\begin{array}{l}\text { Valid } \\
\text { Valid } \\
\text { Valid } \\
\text { Valid } \\
\text { Valid }\end{array}$ & & Reliabel \\
\hline $\begin{array}{c}\text { Kualitas } \\
\left(\mathrm{Y}_{222}\right)\end{array}$ & $\begin{array}{l}\mathrm{Y}_{1.2 .1} \\
\mathrm{Y}_{2,2.2} \\
\mathrm{Y}_{2,2.3} \\
\mathrm{Y}_{22.4} \\
\mathrm{Y}_{2,25}\end{array}$ & $\begin{array}{l}0,829 \\
0,6911 \\
0,811 \\
0,439 \\
0.767\end{array}$ & $\begin{array}{l}0,00 \\
0,000 \\
0,00 \\
0,00 \\
0,00\end{array}$ & $\begin{array}{l}\text { Valid } \\
\text { Valid } \\
\text { Valid } \\
\text { Valid } \\
\text { Valid }\end{array}$ & 0,835 & Reliabcl \\
\hline $\begin{array}{c}\text { Ketepatan } \\
\text { Waktu }\left(Y_{2.3}\right)\end{array}$ & $\begin{array}{l}\mathrm{Y}_{2,3.1} \\
\mathrm{Y}_{2,3.2} \\
\mathrm{Y}_{2,3.3}\end{array}$ & $\begin{array}{l}0,812 \\
0,794 \\
0,7985 \\
0,895\end{array}$ & $\begin{array}{l}0,0 \\
0,00 \\
0,00 \\
0,00\end{array}$ & $\begin{array}{l}\text { Valid } \\
\text { Valid } \\
\text { Valid }\end{array}$ & 0,886 & Reliabel \\
\hline
\end{tabular}

Sumber : Hasil Pengolahan Data Primer, 2015 Semua indikator pada variabel kinerja karyawan menunjukkan hasil yang valid dan reliabel. Keputusan ini diambil karena nilai koefisien korelasi dan cronbach alpha di atas 0,30 atau 0,60, dengan tingkat sangat signifikan $(0,000)$. Indikator yang sangat kuat mencerminkan kinerja karyawan secara berurutan kuantitas $\left(\mathrm{Y}_{1.1}\right)$ dengan nilai cronbach alpha adalah 0,888 , ketepatan waktu $\left(\mathrm{Y}_{2.1}\right)$ dengan nilai cronbach alpha adalah 0,886 , dan kualitas $\left(\mathrm{Y}_{2.2}\right)$ dengan nilai cronbach alpha adalah 0,899.

Berdasarkan tabel diatas terlihat bahwa semua item-item pada variabel pelatihan, promosi, motivasi dan kinerja karyawan valid, karena nilai koefisien korelasinya $\geq 3$ atau sig $\leq 0,05$. Sedangkan untuk uji reliabilitas digunakan nilai Alpha Cronbach, jika nilai Cronbach Alpha lebih dari 0,6 berarti reliabel.

\section{Hasil Analisis Jalur Pengaruh Langsung Variabel Pelatihan $\left(X_{1}\right)$ dan Promosi $\left(\mathbf{X}_{2}\right)$ terhadap Motivasi $\left(\mathbf{Y}_{1}\right)$}

Hasil koefisien jalur menunjukkan bahwa pengaruh variabel pelatihan $\left(\mathrm{X}_{1}\right)$ dan promosi $\left(\mathrm{X}_{2}\right)$ secara positif dan signifikan terhadap motivasi $\left(\mathrm{Y}_{1}\right)$. Penelitian ini ditunjukkan dalam hasil koefisien jalur pada Tabel 55.

\section{Tabel 5}

Hasil Koefisien Jalur Pengaruh langsung Variabel Pelatihan $\left(X_{1}\right)$ dan Promosi $\left(\mathbf{X}_{2}\right)$ Terhadap Motivasi $\left(\mathbf{Y}_{1}\right)$

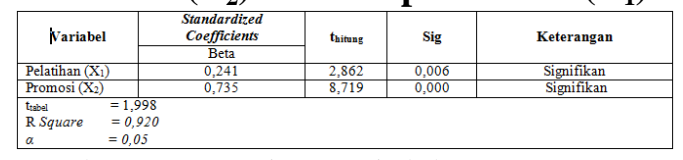

Sumber :Data Primer Diolah 2015

Dari tabel diatas disimpulkan bahwa :

a. Dari nilai $\mathrm{R}$ squere menunjukkan nilai sebesar 0,920 atau $92,0 \%$. Artinya bahwa motivasi dipengaruhi sebesar $92,0 \%$ oleh variabel $\mathrm{X}_{1}$ dan $\mathrm{X}_{2}$. Sedangkan sisanya $8,0 \%$ dipengaruhi oleh variabel lain diluar variabel bebas yang diteliti.

b. Persamaan koefisien jalur $Y_{1}=0,241 X_{1}+0,735 X_{2}$

c. Dari nilai $t_{\text {hitung }}$ dan $t_{\text {tabel }}$ menunjukkan bahwa :

- Hasil perhitungan statistik pengaruh variabel pelatihan $\left(\mathrm{X}_{1}\right)$ terhadap motivasi $\left(\mathrm{Y}_{1}\right)$ memiliki nilai $\mathrm{t}_{\text {hitung }}$ sebesar 2,862. Nilai probabilitas sebesar 0,006 dan koefisien jalur (beta) sebesar 0,241. Karena $t_{\text {hitung }}$ lebih kecil dari $\mathrm{t}_{\text {tabel }}(2,862>1,998)$ atau signifikan > $\% \quad(0,006$ $>0,05)$. Hal ini dapat dijelaskan bahwa apabila nilai $t_{\text {hitung }}$ lebih besar dari $t_{\text {tabel }}$ dan nilai probabilitas lebih kecil dari nilai signifikansi 0,05 serta koefisien jalur (beta) bernilai positif, yang berarti hasil ini adalah signifikan dan positif. Hal ini dapat disimpulkan bahwa pelatihan berpengaruh signifikan dan positif terhadap motivasi. 
- Hasil perhitungan statistik pengaruh variabel promosi $\left(\mathrm{X}_{1}\right)$ terhadap motivasi $\left(\mathrm{Y}_{1}\right)$ memiliki nilai $\mathrm{t}_{\text {hitung }}$ sebesar 8,719. Nilai probabilitas sebesar 0,000 dan koefisien jalur (beta) sebesar 0,241. Karena $t_{\text {hitung }}$ lebih kecil dari $\mathrm{t}_{\text {tabel }}(8,719>1,998)$ atau signifikan $>5 \%(0,000$ $>0,05)$. Hal ini dapat dijelaskan bahwa apabila nilai $t_{\text {hitung }}$ lebih besar dari $t_{\text {tabel }}$ dan nilai probabilitas lebih kecil dari nilai signifikansi 0,05 serta koefisien jalur (beta) bernilai positif, yang berarti hasil ini adalah signifikan dan positif. Hal ini dapat disimpulkan bahwa promosi berpengaruh signifikan dan positif terhadap motivasi.

Hasil Analisis Jalur Variabel Pelatihan $\left(\mathbf{X}_{1}\right)$, Promosi $\left(\mathbf{X}_{2}\right)$ dan Motivasi $\left(\mathbf{Y}_{2}\right)$ Terhadap Kinerja Karyawan $\left(\mathbf{Y}_{2}\right)$

Hasil koefisien jalur menunjukkan bahwa pengaruh variabel pelatihan $\left(\mathrm{X}_{1}\right)$ dan promosi $\left(\mathrm{X}_{2}\right)$ dan motivasi $\left(\mathrm{Y}_{1}\right)$ terhadap kinerja karyawan $\left(\mathrm{Y}_{1}\right)$. Penelitian ini ditunjukkan dalam hasil koefisien jalur pada Tabel 5.12 dibawah ini :

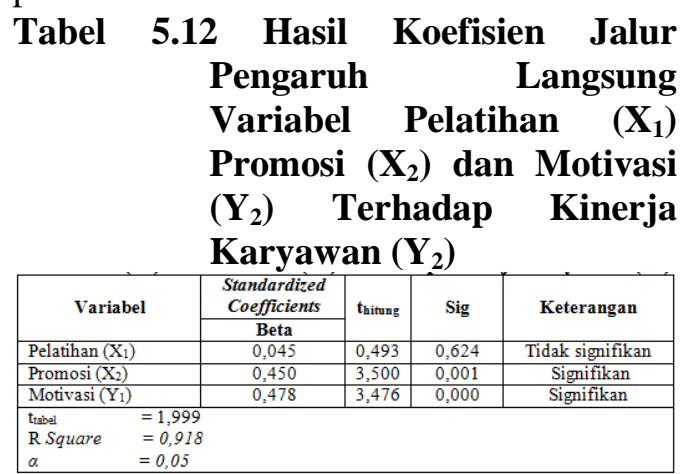

Sumber : Data Primer Diolah 2015

Dari tabel diatas disimpulkan bahwa :

a. Dari nilai $\mathrm{R}$ Square menunjukkan nilai sebesar 0,918 atau 91,8\%. Artinya kinerja karyawan dipengaruhi sebesar $91,8 \%$ oleh karena variabel $X_{1}, X_{2}$ dan $\mathrm{Y}_{1}$. Sedangkan sisanya $8,2 \%$ dipengaruhi oleh variabel lain diluar dari variabel bebas yang diteliti.

b. Persamaan Koefisien jalur (path) $Y_{2}=0,045 X_{1}+0,450 X_{2}+0,478 Y_{1}$ c. Dari nilai $t_{\text {hitung }}$ dan $t_{\text {tabel }}$ menunjukkan bahwa :

- Hasil perhitungan statistik pengaruh variabel pelatihan $\left(\mathrm{X}_{1}\right)$ terhadap variabel kinerja $\left(\mathrm{Y}_{2}\right)$ memiliki nilai $t_{\text {hitung }}$ sebesar 0,493 dengan nilai probabilitas sebesar 0,624 dan koefisien jalur 0,045 . Karena $t_{\text {hitung }}$ lebih besar dari $t_{\text {tabel }}(0,493 \leq 1,999)$ atau sig < $(0,624>0,05)$ maka variabel pelatihan $\left(\mathrm{X}_{1}\right)$ berpengaruh tidak signifikan dan positif terhadap variabel kinerja karyawan $\left(\mathrm{Y}_{2}\right)$.

- Hasil perhitungan statistik pengaruh variabel promosi $\left(\mathrm{X}_{2}\right)$ terhadap variabel kinerja karyawan $\left(\mathrm{Y}_{2}\right)$ memiliki nilai $t_{\text {hitung }}$ sebesar 3,500 dengan nilai probabilitas sebesar 0,001 dan koefisien jalur (beta) sebesar 0,450. Karena $t_{\text {hitung }}$ lebih besar dari $\mathrm{t}_{\text {tabel }}(0,493>1,999)$ atau sig $<5 \%(0,001<0,05)$. Hal ini dapat dijelaskan bahwa apabila nilai $t_{\text {hitung }}$ lebih kecil dari $t_{\text {tabel }}$ dan nilai probabilitas lebih besar dari nilai signifikansi 0,05 , serta koefisien jalur positif, yang berarti hasil adalah signifikan dan positif. Hal ini dapat disimpulkan, bahwa promosi $\left(\mathrm{X}_{2}\right)$ berpengaruh signifikan dan positif terhadap kinerja karyawan $\left(\mathrm{Y}_{2}\right)$.

- Hasil perhitungan statistik pengaruh variabel motivasi $\left(\mathrm{Y}_{1}\right)$ terhadap variabel kinerja karyawan $\left(\mathrm{Y}_{2}\right)$ memiliki nilai $\mathrm{t}_{\text {hitung }}$ sebesar 3,476 dengan nilai probabilitas sebesar 0,000 dan koefisien jalur 0,478. Karena $\mathrm{t}_{\text {hitung }}$ lebih besar dari $\mathrm{t}_{\text {tabel }}$ $(3,478>1,999)$ atau sig < $5 \%(0,000$ $<0,05)$. Hal ini dapat dijelaskan bahwa apabila nilai $t_{\text {hitung }}$ lebih kecil dari $t_{\text {tabel }}$ dan nilai probabilitas lebih besar dari nilai signifikansi 0,05 , serta koefisien jalur positif, yang berarti hasil adalah signifikan dan positif. Hal ini dapat disimpulkan, bahwa pelatihan $\left(\mathrm{X}_{1}\right)$ berpengaruh signifikan dan positif terhadap kinerja karyawan $\left(\mathrm{Y}_{2}\right)$.

$\mathrm{Y}_{1}=0,241 \mathrm{X}_{1}+0,735 \mathrm{X}_{2}$ 
Keterangan :

$\mathrm{Y}_{2}=0,045 \mathrm{X}_{1}+0,450 \mathrm{X}_{2}+0,478 \mathrm{Y}_{1}$

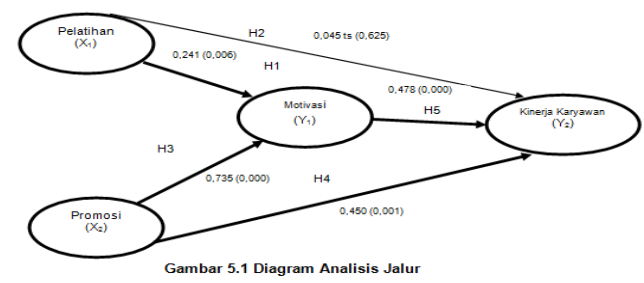

Keterangan:

$$
\begin{array}{ll}
\longrightarrow \quad & =\text { Tidak Signifikan } \\
& =\text { Signifikan }
\end{array}
$$

Tabel 5.14 Hasil Pengujian Hipotesis

\begin{tabular}{|c|l|c|c|c|}
\hline $\begin{array}{c}\text { Variabel } \\
\text { Bebas }\end{array}$ & \multicolumn{1}{|c|}{ Variabel Terikat } & $\begin{array}{c}\text { Koefisi } \\
\text { en Jalur }\end{array}$ & p-value & Keterangan \\
\hline Pelatihan $\left(\mathrm{X}_{1}\right)$ & Motivasi $\left(\mathrm{Y}_{1}\right)$ & 0,241 & 0,006 & Signifikan \\
\hline Pelatihana $\left(\mathrm{X}_{1}\right)$ & Kinerja karyawan $\left(\mathrm{Y}_{2}\right)$ & 0,045 & 0,624 & Tidak signifikan \\
\hline Promosi $\left(\mathrm{X}_{2}\right)$ & Motivasi $\left(\mathrm{Y}_{1}\right)$ & 0,735 & 0,000 & Signifikan \\
\hline Prombsi $\left(\mathrm{Y}_{1}\right)$ & Kinerja karyayawan $\left(\mathrm{Y}_{2}\right)$ & 0,450 & 0,001 & Signifikan \\
\hline Motivasi $\left(\mathrm{Y}_{1}\right)$ & Kinerja karyawan $\left(\mathrm{Y}_{2}\right)$ & 0,478 & 0,000 & Signifikan \\
\hline
\end{tabular}

Sumber : data primer diolah, 2015

\section{Hipotesis 1: Pelatihan Berpengaruh} Signifikan Terhadap Motivasi

Hasil koefisien jalur pengaruh langsung pelatihan terhadap motivasi dengan nilai 0,241 dengan $p$-value $=0,006$ . Karena >0,05. maka ada pengaruh signifikan antara variabel pelatihan $\left(\mathrm{X}_{1}\right)$ terhadap Variabel motivasi $\left(\mathrm{Y}_{2}\right)$, sehingga dapat disimpulkan bahwa $\mathrm{H}_{1}$ terima. Mengingat koefisien bertanda positif dan signifikan dapat disimpulkan bahwa pengaruh antara keduahnya searah. artinya semakin baik suatu pelatihan maka semakin meningkat pula motivasi karyawan pada PT.PLN (Persero) Area Kendari.

\section{Hipotesis 2: Pelatihan Berpengaruh Signifikan Terhadap Kinerja Karyawan}

Hasil koefisien jalur pengaruh langsung pelatihan terhadap kinerja karyawan dengan nilai 0,045 dengan $p$ value $=0,624$. Karena $p$-value $>0,05$, maka ada pengaruh tidak signifikan variabel pelatihan $\left(\mathrm{X}_{1}\right)$ terhadap variabel kinerja karyawan $\left(\mathrm{Y}_{2}\right)$ sehingga dapat disimpulkan $\mathrm{H}_{2}$ ditolak dan $\mathrm{H}_{0}$ diterima. Mengingat koefisien bertanda positif dan tidak signifikan dapat disimpulkan bahwa Pengaruh antara keduanya searah tetapi tidak bermakna. Artinya semakin baik pelatihan belum menjamin kinerja karyawan PT. PLN (Persero) Area Kendari meningkat.

\section{Hipotesis 3 : Promosi Berpengaruh Signifikan Terhadap Motivasi}

Hasil koefisien jalur pengaruh langsung promosi terhadap motivasi dengan nilai 0,735 dengan $p$-value $=0,000$ karena $p$-value $<0,05$, maka ada pengaruh signifikan antara variabel promosi $\left(\mathrm{X}_{2}\right)$ terhadap variabel motivasi $\left(\mathrm{Y}_{1}\right)$, sehingga dapat disimpulkan bahwa $\mathrm{H}_{3}$ diterima. Mengingat koefisien bertanda positif dan signifikan dapat disimpulakan bahwa pengaruh antara keduanya adalah searah, artinya semakin baik promosi semakin meningkat pula motivasi karyawan PT.PLN (Persero) Area Kendari.

\section{Hipotesis 4 : Promosi Berpengaruh Signifikan Terhadap Kinerja Karyawan}

Hasil koefisien jalur pengaruh langsung promosi terhadap kinerja karyawan dengan nilai 0,450 dengan $p$ value $=0,001$ karena $p$-value $<0,05$, maka ada pengaruh signifikan antara variabel promosi $\left(\mathrm{X}_{2}\right)$ terhadap kinerja karyawan $\left(\mathrm{X}_{2}\right)$, sehingga dapat disimpulkan bahwa $\mathrm{H}_{4}$ diterima. Mengingat koefisien bertanda positif dan signifikan dapat disimpulakan bahwa pengaruh antara keduanya adalah searah, artinya semakin baik promosi semakin memperbaiki kinerja karyawan PT.PLN (Persero) Area Kendari.

\section{Hipotesis 5 : Motivasi Berpengaruh} Signifikan Terhadap Kinerja Karyawan

Hasil koefisien jalur pengaruh langsung motivasi terhadap kinerja karyawan dengan nilai 0,478 dengan $p$ value $=0,000$ karena $p$-value $<0,05$, maka 
ada pengaruh antara variabel motivasi $\left(\mathrm{Y}_{1}\right)$ berpengaruh signifikan terhadap kinerja karyawan $\left(\mathrm{Y}_{2}\right)$, sehingga dapat disimpulkan $\mathrm{H}_{5}$ diterima. Mengingat koefisien bertanda positif dan signifikan dapat disimpulakan bahwa pengaruh antara keduanya adalah searah, artinya semakin baik motivasi semakin memperbaiki kinerja karyawan.

\section{Pembahasan}

Hasil temuan pertama, yaitu $\mathrm{H}_{1}$ yang menyatakan ada pengaruh signifikan antara variabel pelatihan $\left(\mathrm{X}_{1}\right)$ terhadap variabel Motivasi $\left(\mathrm{Y}_{2}\right)$ dapat diterima. $\mathrm{H}_{1}$ dibuktikan melalui analisis jalur pengaruh variabel pelatihan terhadap variabel motivasi $\left(\mathrm{Y}_{2}\right)$ yang memiliki nilai probabbilitas sebesar $0,006 P$ value $\leq \alpha$ $(0,006 \leq 0,05)$ artinya signifikan. Koefisien jalur sebesar 0,241 menunjukkan pengaruh antara variabel pelatihan $\left(\mathrm{X}_{1}\right)$ terhadap variabel motivasi $\left(\mathrm{Y}_{2}\right)$ positif. Artinya semakin baik pelatihan yang diberikan pada para karyawan, maka motivasi dari karyawan tersebut akan semakin meningkat. Hal ini membuktikan bahwa pelatihan bisa meningkatkan motivasi karyawan PT. PLN (Persero) Area Kendari. PT. PLN (Persero) Area Kendari telah mengadakan dua hal mengenai pelatihan yaitu Training Need Analysis (TNA) dan Learning Need Analysis (LNA), pelatihan ini bertujuan untuk meningkatkan motivasi karyawan agar membuat karyawan memiliki semangat kerja di dalam rutinitas yang penuh tanggung jawab, tindakan, kualitas, kesadaran dan kemauan untuk melakukan pencapaian yang terbaik.

Berdasarkan hasil statistik deskriptif variabel pelatihan $\left(\mathrm{X}_{1}\right)$ dipersepsikan oleh responden, dengan nilai rata-rata variabel 3,62 dan variabel motivasi $\left(\mathrm{Y}_{1}\right)$ dipersepsikan baik oleh responden 4,15. Hal ini terbukti dengan semakin baik pelatihan yang diberikan maka, semakin meningkat pula motivasi karyawan. Sehingga dapat dikatakan bahwa terdapat pengaruh signifikan dan positif terhadap motivasi.

Pada penelitian ini membuktikan bahwa bukan hanya pelatihan yang dapat meningkatkan motivasi. Secara empiris terdiri dari atas instruktur, metode, waktu dan manfaat pelatihan. Seluruh komponen telah dinilai baik oleh responden terutama dari unsur manfaat pelatihan yang terkesan program pelatihan dapat meningkatkan keahlian, program pelatihan dapat meningkatkan keterampilan, program pelatihan dapat memperbaiki kinerja, program pelatihan mampu meningkatkan motivasi kerja dalam setiap situasi, program pelatihan mampu meningkatkan motivasi untuk memberikan pelayanan berkualitas di internal perusahaan.

Hasil ini sesuai dengan pendapat MC Gehe dalam Mangkunegara, (2009:65) yang menyatakan bahwa pelatih harus mampu memotivasi dan pelatihan itu harus dapat meningkatkan moral dan semangat kerja serta meningkatkan motivasi kerja. Selain oleh hasil penelitian ini juga sesuai dengan penelitian yang dilakukan oleh Tabassi et al (2012) menyatakan bahwa pelatihan berpengaruh signifikan terhadap motivasi

Hasil temuan pertama, yaitu $\mathrm{H}_{2}$ yang menyatakan hasil analisis pengaruh langsung pelatihan terhadap kinerja karyawan diperoleh nilai koefisien jalur positif tidak signifikan yang berarti ditolak. $\mathrm{H}_{2}$ melalui analisis jalur pengaruh variabel pelatihan $\left(\mathrm{X}_{1}\right)$ terhadap variabel kinerja karyawan $\left(\mathrm{Y}_{2}\right)$ yang memiliki nilai probabilitas sebesar $0,624, p$ value $\geq \alpha$ $(0,624 \geq 0,05)$ artinya tidak signifikan. Hal ini menunjukkan bahwa Koefisien jalur bertanda positif dan tidak signifikan. Pelatihan yang diadakan di PT.PLN (Persero) Area Kendari sudah baik namun bukan jaminan dalam memperbaiki kinerja karyawan. Hal ini terbukti dengan semakin baik pelatihan yang diberikan maka, semakin meningkat pula kinerja karyawan. Sehingga dapat disimpulkan bahwa penelitian ini secara teori berhubungan dan tidak didukung dengan data empiris. 
Hasil ini tidak sejalan dengan penelitian yang dilakukan oleh Erlanga dan Imran (2013) yang memberikan gambaran tentang pelatihan yang efektif dan bagaimana cara berkontribusi untuk meningkatkan kinerja. Oleh karena itu jika metode pelatihan sesuai dengan materi pelatihan, penempatan sesuai dengan bidangnya dan sarana dan prasarana diperhatikan dengan baik maka pelatihan dapat memperbaiki dan meningkatkan kinerja karyawan pada PT.PLN (Area) Kendari. Hal ini sejalan dengan penelitian yang dilakukan oleh Onyango (2014) menyatakan bahwa tidak ada pengaruh yang signifikan antara pelatihan terhadap kinerja karyawan. Sejalan dengan penelitian yang dilakukan Saputra et al, menunjukkan hasil penelitian variabel pelatihan berpengaruh tidak signifikan terhadap kinerja karyawan.

Hasil temuan ketiga, yaitu $\mathrm{H}_{3}$ yang menyatakan ada pengaruh signifikan antara variabel promosi $\left(\mathrm{X}_{2}\right)$ terhadap variabel motivasi $\left(\mathrm{Y}_{1}\right)$ dapat diterima. $\mathrm{H}_{3}$ dibuktikan melalui hasil analisis jalur pengaruh variabel promosi $\left(\mathrm{X}_{2}\right)$ terhadap variabel motivasi $\left(\mathrm{Y}_{1}\right)$ yang memiliki nilai probabilitas sebesar $0,001, p$ value $\leq \alpha$ $(0,001 \leq 0,05)$ artinya signifikan. Koefisien jalur sebesar 0,450 menunjukkan pengaruh antara variabel promosi $\left(\mathrm{X}_{2}\right)$ terhadap variabel motivasi $\left(\mathrm{Y}_{1}\right)$ positif artinya semakin baik pelaksanaan promosi maka motivasi karyawan PT. PLN (Persero) Area Kendari akan semakin baik. Hal ini dikarena PT. PLN (Persero ) Area Kendari telah menerapkan kebijakan promosi berdasarkan asas kepercayaan, asas keadilan, senioritas, prestasi kerja, loyalitas, dan kejujuran.

Dari hasil analisis deskripsi promosi dipersepsikan baik oleh karyawan pada PT.PLN (Persero) Area Kendari. Skor rata-rata tertinggi pada senioritas artinya karyawan mempersepsikan bahwa didalam melaksanakan promosi karyawan harus memiliki pengalaman kerja dan wawasan yang luas. Hal ini memberikan pengaruh dalam perusahaan karena dengan memperhatikan kriteria dalam promosi pangkat hal itu dapat menjadi motivasi kerja bagi karyawan pada PT.PLN (Persero) Area Kendari.

Penelitian ini sesuai pendapat yang dikemukakan oleh Hasibuan (2003:109) merupakan promosi memberikan kebaikan-kebaikan antara lain yaitu memotivasi karyawan untuk memperdalam pengetahuan dam memotivasi berkembangnya persaingan yang sehat dinamis diantara karyawan sehingga mereka berlomba-lomba untuk mencapai kemajuan. Promosi yang didasarkan pada prestasi kerja menggunakan hasil penilaian atas hasil karya yang sangat baik dalam promosi atau jabatan sekarang. Dengan demikian promosi dapat dipandang sebagai penghargaan organisasi atas prestasi kerja anggotanya, perlu disadari bahwa mempromosikan seseorang bukannya tanpa resiko, dalam arti bahwa tidak ada jaminan penuh bahwa orang yang dipromosikan benar-benar memenuhi harapan organisasi. Hal ini sejalan dengan penelitian yang dilakukan oleh Takashi (2006) menunjukkan bahwa promosi mempengaruhi motivasi kerja karyawan sejalan dengan penelitian Yanuarmawan yang menyatakan bahwa promosi berpengaruh signifikan terhadap motivasi karyawan.

Hasil temuan keempat, yaitu $\mathrm{H}_{4}$ yang menyatakan ada pengaruh signifikan antara variabel promosi $\left(\mathrm{X}_{2}\right)$ terhadap variabel kinerja karyawan $\left(\mathrm{Y}_{2}\right)$ dapat diterima. $\mathrm{H}_{4}$ dibuktikan melalui hasil analisis jalur pengaruh variabel promosi $\left(\mathrm{X}_{2}\right)$ terhadap variabel kinerja karyawan $\left(\mathrm{Y}_{2}\right)$ yang memiliki nilai probabilitas sebesar $0,450, \leq \alpha(0,450 \leq 0,05)$ artinya signifikan. Koefisien jalur sebesar 0,450 menunjukkan pengaruh antara variabel promosi $\left(\mathrm{X}_{2}\right)$ terhadap variabel kinerja karyawan $\left(\mathrm{Y}_{2}\right)$ positif artinya semakin baik pelaksanaan kebijakan promosi maka kinerja karyawan PT. PLN (Persero) Area Kendari akan semakin baik. Hal ini dikarenakan bahwa promosi dapat memungkinkan perusahaan memanfaat 
kemampuan karyawan untuk memperluas usahanya dan dapat mendorong tercapai kinerja karyawan yang baik. Karyawan umumnya berupaya melakukan pekerjaan sebaik mungkin jika mereka percaya bahwa kinerja tinggi mengarah pada adanya promosi. Hal ini menunjukkan bahwa promosi berpengaruh terhadap kinerja karyawan. Koefisien jalur bertanda positif berarti terdapat pengaruh searah antara promosi dengan kinerja karyawan. Pengaruh promosi sangat berpengaruh dalam meningkatkan kinerja karyawan pada PT.PLN (Persero) Area Kendari.

Dari hasil analisis deskripsi promosi dipersepsikan baik oleh karyawan pada PT.PLN (Persero) Area Kendari. Skor rata-rata tertinggi pada senioritas artinya karyawan mempersepsikan bahwa didalam melaksanakan promosi karyawan harus memiliki pengalaman kerja dan wawasan yang luas. Hal ini memberikan pengaruh dalam perusahaan karena dengan memperhatikan kriteria dalam promosi dapat meningkatkan kinerja karyawan PT.PLN (Persero) Area Kendari. Hal ini didukung dengan penelitian yang dilakukan oleh Odinga dan Edward (2012) menunjukkan bahwa ada hubungan antara promosi terhadap kinerja karyawan.

Hasil temuan kelima, yaitu $\mathrm{H}_{5}$ yang menyatakan ada pengaruh signifikan antara motivasi $\left(\mathrm{Y}_{1}\right)$ terhadap kinerja karyawan $\left(\mathrm{Y}_{2}\right)$ dapat diterima. $\mathrm{H}_{5}$ dibuktikan melalui analisis jalur pengaruh antara motivasi $\left(\mathrm{Y}_{1}\right)$ terhadap kinerja karyawan $\left(\mathrm{Y}_{2}\right)$ yang memiliki nilai probabilitas sebesar $0,478, \leq \alpha(0,478 \leq$ $0,05)$ artinya signifikan. Koefisien jalur sebesar 0,000 menunjukkan pengaruh motivasi $\left(\mathrm{Y}_{1}\right)$ terhadap kinerja karyawan $\left(\mathrm{Y}_{2}\right)$ positif artinya semakin meningkat motivasi karyawan akan membuat kinerja karyawan meningkat. Hal ini dikarenakan motivasi kerja karyawan selalu terjaga dengan baik karena rata-rata karyawan sudah mampu memenuhi pokonya menggunakan pendapatan yang diperoleh dari PT.PLN (Persero) Area Malang dan selama bekerja karyawan telah merasa keamanan terjamin oleh PT.PLN (Persero) Area Kendari. Selain itu hubungan kerja sama selalu terjalin dengan baik. Hal ini yang membuat motivasi kerja karyawan meningkat sehingga memiliki dampak positif terhadap kinerja dalam memperbaiki kinerja karyawan.

Hasil ini didukung dengan penelitian yang dilakukan Tabassi et al (2012) dan, Darminto (2000), menyatakan bahwa terdapat pengaruh yang signifikan antara motivasi dan kinerja karyawan. Hasil penelitian ini juga sesuai dengan pendapat Davis dan Robbins (2006:241) yang menyatakan bahwa motivasi merupakan salah satu faktor yang mempengaruhi kinerja karyawan.

\section{SIMPULAN}

Berdasarkan hasil analisis statistik data penelitian baik secara deskiptif maupun secara inferensial yang telah dilakukan terhadap teori dan modal hipotesis penelitian ini, maka dapat disimpulkan sebagai berikut :

1. Pelatihan berpengaruh signifikan dan positif terhadap motivasi karyawan. Hal ini menunjukkan bahwa variabel pelatihan yang ditunjukkan oleh indikator pelatihan instruktur, metode pelatihan, waktu pelatihan dan manfaat pelatihan dapat memotivasi karyawan PT.PLN (Persero) Area Kendari. Dengan demikian dapat disimpulkan bahwa jika pelatihan dilaksanakan dengan baik maka motivasi akan semakin meningkat.

2. Pelatihan berpengaruh tidak signifikan dan positif terhadap kinerja karyawan. Hal ini menunjukkan bahwa penelitian tidak didukung dengan data empris, sehingga dapat disimpulkan bahwa pelatihan yang baik dapat meningkatkan kinerja karyawan, namun ketidak sesuai metode pelatihan dengan materi yang dibawakan dalam melaksanan pelatihan dapat menurunkan kinerja karyawan. 
3. Promosi berpengaruh signifikan dan positif terhadap motivasi. Hal ini menunjukkan bahwa variabel promosi yang ditunjukkan oleh indikator asas kepercayaan, asas keadilan, senioritas, prestasi kerja, loyalitas dan kejujuran dapat memotivasi karyawan PT.PLN (Persero) Area Kendari. Dengan demikian dapat disimpulkan bahwa semakin baik suatu promosi dapat meningkatkan motivasi karyawan, Oleh karena itu, kebijakan promosi di PT. PLN (Persero) Area Karena sudah berdasarkan keadilan dimana kebijakan yang diambil oleh pemimpin sudah memberikan gagasan mengenai penilai tentang promosi karyawan yang melihat dari segi prestasi kerja karyawan sehingga dengan adanya hal tersebut dapat memotivasi karyawan dalam bekerja.

4. Promosi berpengaruh signifikan dan positif terhadap kinerja karyawan. Hal ini menunjukkan bahwa variabel promosi yang ditunjukkan oleh indikator asas kepercayaan, asas keadilan, senioritas, prestasi kerja, loyalitas dan kejujuran dapat memotivasi karyawan PT.PLN (Persero) Area Kendari. hal ini dapat disimpulkan bahwa persepsi karyawan baik terkait dengan kebijakan promosi di PT. PLN (Persero) Area Karena sudah berdasarkan pimpinan diharapkan memiliki penilaian yang baik dan adil terhadap karyawan yang akan dipromosikan. Hal ini dikarenakan setiap karyawan mendambakan untuk dipromosikan. Promosi pangkat dipandang sebagai bentuk acuan untuk mencapai keberhasilan karyawan dalam mencapai prestasi kerja yang tinggi dalam menunaikan kewajiban pada pekerjaan dan jabatan pekerjaan dan jabatan yang dijabatnya sekarang. Promosi memberikan peranan penting bagi setiap karyawan, Bahkan menjadi idaman yang selalu dinanti-nantikan oleh karyawan.
Kerena dengan promosi berarti ada kepercayaan dan pengakuan mengenai kemampuan serta kecakapan pegawai bersangkutan untuk menjabat suatu jabatan yang lebih tinggi. Dengan demikian, promosi akan selalu diikuti tugas, tanggung jawab dan wewenang yang lebih tinggi dari jabatan yang diduduki sebelumnya. Dan pada umumnya diikuti oleh peningkatan pendapatan dan fasilitas. Sehingga prosedur yang dilakukan harus adil sehingga tidak terjadi negosiasi antara bawahan dengan atasan

5. Motivasi berpengaruh signifikan dan positif kinerja karyawan. Hal ini menunjukkan bahwa variabel motivasi yang ditunjukkan indikator kebutuhan eksistensi, kebutuhan relasi dan kebutuhan pertumbuhan dapat memotivasi karyawan PT. PLN (Persero) Area Kendari. Motivasi merupakan variabel bermakna dalam meningkatkan kinerja karyawan dalam memperbaiki kinerja karyawan. Artinya semakin baik motivasi maka dapat meningkatkan kinerja karyawan. Motivasi karyawan yang baik karena merasa yakin akan kebutuhan dalam berelasi melihat hubungan baik sesama pekerja dan atasan selanjutnya, merasa mendapat kesempatan untuk maju dan karena mendapat kesempatan untuk memberi saran dan gagasan. Motivasi kerja karyawan semakin baik karena komunikasi dan kerja sama telah berjalan dengan baik serta organisasi melibatkan karyawan ikut berkontribusi menyumbangkan pemikirannya untuk organisasi.

\section{DAFTAR PUSTAKA}

Aryani, Y., Dhewi, R. M., dan Mangkuprawira, S. (2010). Analisis Pengaruh Sistem Promosi Jabatan terhadap Kinerja Karyawan pada 
Divisi Human Resources and General Affairs PT Indocement Tunggal Prakarsa, Tbk Citeureup. Vol.1, No.3, pp.123-126.

Hariandja, Marihot Tua Efendi.2002. Manajemen Sumber daya Manusia. PT. Gramedia Widiasarana Indonesia. Jakarta.

Mangkunegara, Anwar. 2002. Organization. Perilaku Konsumen, PT. Rafika Aditama, Bandung.

Shaheen.A, Mubasher Syed H. N dan Atif Muhammad Khan (2013). “ Employee Training and organizational Performance: Mediation by Employees Performance.Interdisiplinary Journal of Comtemporary research in Busines, Vol 5, No. 4. pp. 490-499.

Sugiono 2008. Metode Penelitian Administrasi., Alfabeta. Bandung

Sultana, A., Irum, S., Ahmed, K., dan Mehmood, N. (2012). Impact Of Training on Employee Performance: A Study of Telecommunication Sector in Pakistan.Interdisciplinary Journal of Contemporary Research in Business, Vol.4, No.6. pp. 646-661.

Onyango, J. W. (2014). Effects Of Training On Employee Performance: A Survey Of Health Workers In Siaya County, Kenya. European Journal of Environmental

Sciences, Vol.1, No.1,pp.1115.

Ondinga Maryjulie dan Edward Fred K Bakkabulindi (2012). Staff
Trainning And Promotion As Correlates Of Job Perforfance Of Lectures In Moi University. African journal of business and Managemen, Vol 2. No.1 pp. 48-59.

Tabassi, A. A., Ramli, M., dan Bakar, A. H. A. 2012. Effects Of Training And Motivation Practices On Teamwork Improvement And Task Efficiency: The Case of Construction

Firms. International Journal of Project Management, Vol.30, No.2. pp. 213-224.

Yanuarmawan. 2012. Pengaruh Promosi Jabatan Terhadap Kinerja Dikaji Menurut Teori Alderfer (Studi di PT. BPR Gunung Ringgit Malang). Jurnal Akuntansi dan Ekonomi Bisnis. Vol 1. No.1, pp. 117- 